\section{The role of foreign direct investment in growth: Spain, 1964-2013}

Role of foreign
direct
investment in
growth

263

Department of Economics, Universidad de Castilla-La Mancha, Ciudad Real, Spain

\begin{abstract}
Purpose - Foreign direct investment (FDI) has played a major role in the deep process of transformation experienced by the Spanish economy since the first 1960s, which even intensified, following the integration with the now European Union in 1986. This paper aims to analyse the long-run effects of FDI in Spain by estimating a production function including the foreign capital stock over the period 1964-2013.

Design/methodology/approach - The author estimates a production function including the foreign capital stock over the period 1964-2013, from which the contributions of the different explanatory variables on the accumulated growth of gross domestic product (GDP) are computed. Next, the author tested for the possible presence of structural change in the previously estimated equation, by means of the tests of Bai and Perron, re-estimating the production function for the different subperiods delimited by the structural breaks found. Finally, the analysis is completed by performing Granger-causality tests on the variables GDP and foreign capital stock in a multivariate setting.

Findings - The author finds a significant contribution of foreign capital on the accumulated growth of GDP over the period of analysis, which seems however to have been greater during the first years of the period analysed. Foreign capital can play a positive role in the economic growth of an economy, provided that FDI inflows are stable and permanent enough, but this effect on growth seems to be more important in the first stages of a growth process.

Originality/value - The author presents a comprehensive analysis of the relationship between FDI and growth for a particular country, which seems to be a more promising empirical approach rather than the approach based on panel regressions, where sometimes some dissimilar experiences are added together. The Spanish economy can provide a relevant case study, given the substantial process of growth it enjoyed starting from the early 1960s, characterized by the arrival of vast inflows of foreign capital.
\end{abstract}

Keywords Economic growth, Foreign direct investment

Paper type Research paper

(C) Oscar Bajo-Rubio. Published in Applied Economic Analysis. Published by Emerald Publishing Limited. This article is published under the Creative Commons Attribution (CC BY 4.0) licence. Anyone may reproduce, distribute, translate and create derivative works of this article (for both commercial and non-commercial purposes), subject to full attribution to the original publication and authors. The full terms of this licence maybe seen at http://creativecommons.org/licences/by/4.0/ legalcode

JEL classification - F21, F43, O40

The author acknowledges financial support from the University of Castilla-La Mancha through the project 2020-GRIN-29041, co-financed by the European Union via the European Regional Development Fund. Useful comments from two anonymous referees of this journal, and from the participants at the IV Research Meeting on Internationalization, organised by the Nebrija-Santander Global Chair on Business Internationalization and the Complutense Institute for International Studies (Madrid, May 2021) are also gratefully acknowledged. Revised 18September 2021 20 September 2021 Accepted 25 September 2021
Received 6 July 2021 
AEA

30,90

\section{Introduction}

Foreign direct investment (FDI) has played an increasing role as a way of internationalization of the economic activity since the end of Second World War. In fact, FDI is one of the most relevant aspects of the current wave of globalization, recording higher growth rates than both the world trade and output.

The role of FDI on economic growth has been extensively analysed in the past years, by means of multivariate regressions over long-time spans, where either gross domestic product (GDP) or its rate growth was made dependent on a series of macroeconomic variables, including the ratio of FDI inflows to GDP. A common result of this literature is that FDI shows a positive and significant influence on growth, although this effect would be stronger if host countries possess a minimum absorptive capacity able to channel FDI flows towards an increase in output. Some contributions to this literature would include, among many others, Blomström et al. (1994); Balasubramanyam et al. (1996), Borensztein et al. (1998); de Mello (1999), Campos and Kinoshita (2002); Durham (2004), Alfaro et al. (2004); Laureti and Postiglione (2005), Tang et al. (2008); Adams (2009); Bajo-Rubio et al. (2010); Omri and Kahouli (2014); or Iamsiraroj (2016). A common feature of most of the available studies, though, is that they make use of cross-sections of a set of countries, hence not analysing the case of individual countries. However, given the great heterogeneity of country experiences, such an approach could mean adding together some too dissimilar experiences, so that focussing on specific countries might be a more promising empirical approach.

Accordingly, in this paper, we will analyse the relationship between FDI and growth for a particular country, i.e. Spain, over the period 1964-2013. The Spanish economy can provide a relevant case study, given the substantial process of growth it enjoyed starting from the early 1960s. In addition, FDI was a crucial factor in this process of intense transformation over the 1960s, and, even more, the massive increase in FDI inflows following the Spanish integration with the now European Union (EU) in 1986, coupled with the prospects about the completion of the single European market by 1992, meant one of the most important features shaping the behaviour of the Spanish economy until the start of the Great Recession. An overview of FDI trends following the integration into the EU can be found in Bajo-Rubio and Torres (1992).

The objective of this paper is to analyse the long-run effects of FDI for the case of Spain by estimating a production function, including the foreign capital stock, over the period 1964-2013. In addition to the additional insight that this exercise might provide on the role of FDI in the Spanish economy, the Spanish case might be of interest for other reasons. Spain can be considered a medium-sized economy, given the size of its main macroeconomic variables, which has experienced a process of rapid growth since the early 1960s, starting from a relatively weaker position than the rest of Western European countries. This has been particularly true after joining the EU in 1986, allowing it an even deeper integration with other more advanced economies, so Spain has been able to join the Economic and Monetary Union (EMU) from its start. In sum, the Spanish experience could be of interest for other medium-sized economies expected to follow a process of integration with other relatively more advanced countries.

There are several studies available that investigate the main features of FDI in the Spanish economy together with their economic implications. In particular, the macroeconomic factors behind the FDI inflows received between 1964 and 1989 were analysed in Bajo-Rubio and Sosvilla-Rivero (1994), and the sectoral allocation of FDI in manufacturing was examined in Bajo-Rubio and López-Pueyo (2002); further contributions in this line include Rodríguez and Pallas (2008) and Villaverde and Maza (2012), the latter focussing on regional issues. A general survey on the role of FDI in the Spanish economy is 
Fernández-Otheo (2003), and a comprehensive study of the subject can be found in the different contributions included in Myro (2014).

However, and despite the importance of FDI in the Spanish economy, their macroeconomic effects have been hardly explored; an exception is Sosvilla-Rivero and Herce (1998), where the role of FDI in fostering the favourable effects of the European Single Market was stressed. Regarding its growth effects, Bajo-Rubio et al. (2010) analysed the impact of FDI on growth at a regional level over the period following the integration within the EU, i.e. 1987-2000. This paper found a positive influence of accumulated FDI inflows (as a proxy of the foreign capital stock) on the evolution of GDP per employee and, eventually, on regional growth, provided that the host economies have an appropriate level of development, and hence the necessary absorptive capacity of FDI. Later on, BermejoCarbonell and Werner (2018) obtained no significant positive effect on Spanish GDP growth from FDI, as well as from joining the EU or adopting the euro, for the period 1984-2010. The authors, in turn, stress the role of bank credit creation, from the estimation of an equation adding together several financial variables and FDI inflows (unlike the above quoted paper, which used a proxy of the stock of FDI), not derived from any specific model. Finally, Gutiérrez-Portilla et al. (2019) revisit the effect of FDI on regional economic growth over the period 1996-2013, paying a special attention to the "headquarters effect", i.e. the fact that FDI is not always registered in the region where is effectively made but in the region where the firm's headquarters are located. They found that FDI (measured as the accumulated sum of inflows, as in Bajo-Rubio et al., 2010) promotes economic growth, but once the headquarters effect is properly addressed, spatial spillovers arise, so that economic growth in a region is positively affected not only by the FDI received in that region but also by the FDI received in neighbouring regions.

The rest of the paper is organized as follows. The theoretical framework is presented in Section 2. The data and empirical results are discussed in Section 3. The main conclusions are summarized in Section 4.

\section{Theoretical framework}

Our starting point will be a simple production function, including human capital (as in Mankiw, Romer and Weil, 1992), written as follows for simplicity in a Cobb-Douglas form:

$$
Y_{t}=A_{t} K_{t}^{\alpha} N_{t}^{\beta} H_{t}^{\gamma}
$$

where $Y, K, N$ and $H$ denote, respectively, output, physical capital, labour and human capital, and $A$ is an index of the level of technology. By taking logs, the above equation becomes as follows:

$$
L Y_{t}=L A_{t}+\alpha L K_{t}+\beta L N_{t}+\gamma L H_{t}
$$

where $L$ denotes natural logarithm.

How does FDI enter the above equation? In the next paragraphs, we will review some theoretical arguments on the relationship between FDI, productivity growth and technological innovation made by the multinational enterprise (MNE).

In the standard neoclassical growth model, FDI is simply assumed to be an addition to the capital stock of the host economy (Brems, 1970), so the effect of foreign capital would be indistinguishable from that of domestic capital. Notice that, in this case, if returns to capital are diminishing, FDI would affect growth only in the short run, i.e. during the transition to the steady-state growth path, which seems to be rather unsatisfactory, given the recent
Role of foreign direct investment in growth 
AEA

30,90

266

trends in FDI. Indeed, the main role of FDI seems to be transferring assets from less efficient to more efficient owners, so in practice, FDI consists of offsetting two-way flows that are hardly related to productive investment (Lipsey, 2001). In other words, FDI would be less and less of the "greenfield" type, i.e. FDI devoted to enlarging the production capacity of the host economy.

Endogenous growth models allow for a greater impact of FDI on growth. In principle, FDI could lead to externalities on the domestic production factors, although its effect on growth would be permanent only in the presence of increasing returns to scale over all factors (i.e. including the externality). Even more, this literature has developed formal models for technological innovation, which emerges as a response to economic incentives, that is, profit opportunities detected by firms that are influenced by the institutional, legal and economic environment in which they act (Grossman and Helpman, 1994). All this, in turn, amounts to emphasize the role of FDI and, in general, the degree of economic integration as an important factor shaping technological progress and hence growth rates.

Thus, higher integration means an increase in market size resulting in greater incentives to R\&D and so higher growth, which in turn enables the diffusion of knowledge across countries and avoids duplication of the research activity (Romer, 1990; Grossman and Helpman, 1991). In particular, integration among relatively similar economies should result in higher growth over the long run, allowing the exploitation at the world level of the increasing returns present in the R\&D sector (Rivera-Batiz and Romer, 1991).

Another issue extensively analysed in the literature is the possible presence of spillovers of the MNEs activities. Specifically, establishing a subsidiary might lead to productivity or efficiency benefits for the host country's local firms, provided that the MNEs are not able to internalize the full value of these benefits (Blomström and Kokko, 1998). In other words, local firms in the host country can benefit from the more evolved production methods, organizational and managerial techniques, marketing activities, and the like, of the MNEs, through several channels such as imitation, the higher competition associated with the presence of the subsidiary, or the mobility of the labour force previously trained and familiar with the more advanced techniques developed by the MNEs (Görg and Greenaway, 2004).

The empirical evidence on these spillover effects is far from being unambiguous. As noticed by Aitken and Harrison (1999), the positive spillover effects would shift the average costs curve of domestic firms downwards, but the increased competition would lead these firms to reduce their output and so moving along the new average costs curve upwards, so the net effect on average costs would be ambiguous. On the other hand, not all domestic firms would benefit equally from these spillover effects, but rather those enjoying a higher absorptive capacity of the new technologies, or those located geographically closer to the subsidiary of the MNE (Görg and Greenaway, 2004). Even more, in terms of the development of local industry, the positive spillovers associated with FDI would dominate when inflows are large, outweighing the negative competition effects associated with FDI, as shown in Barrios et al. (2005). Most generally, a greater opening to FDI inflows from the most advanced countries would lead to higher rates of both the technological progress and growth in the host country (Wang, 1990), and the incentive of an MNE to transfer technologies via FDI would depend negatively on its perceived operation risks in the host country and positively on the investment in learning made by the host country's firms (Wang and Blomström, 1992).

Therefore, according to the previous theoretical arguments, we will assume that the level of technology $A$ depends on its initial value, $A_{0}$, and the foreign capital stock, $F K$ : 


$$
A_{t}=A_{0} F K_{\mathrm{t}}^{\theta}
$$

(3) Role of foreign direct

where $F K$ will be proxied by the accumulated sum of FDI inflows, which, in logs, becomes as follows:

$$
L A_{t}=L A_{0}+\theta L F K_{t}
$$

And, replacing equation (4) in equation (2), we get:

$$
L Y_{t}=L A_{0}+\alpha L K_{t}+\beta L N_{t}+\gamma L H_{t}+\theta L F K_{t}
$$

which will be the equation to be estimated in Section 3 .

\section{Data and empirical results}

In this section, we will present some econometric estimates of the above production function for the Spanish economy to quantify the effects of accumulated FDI inflows on aggregate output. The data are annual for the period 1964-2013, and the variables used and their sources are as follows:

- GDP and its deflator, million euros. Source: Eurostat;

- Physical capital stock: net capital stock, million euros. Source: Fundación BBVA and Ivie (2019);

- Human capital stock: sum of the employed population with medium (i.e. secondary) and two levels of higher education (i.e. first cycle or shorter courses and second cycle or full-length courses) thousand persons. Source: Mas et al. (2014);

- Total employed population, thousand persons: Mas et al. (2014); and

- Accumulated sum of FDI gross receipts since 1960, net of disinvestments payments, million euros. Source: Spanish Balance of Payments, elaborated by the Bank of Spain [1].

The variables in real terms are valued at 2015 prices. The choice of the sample period is dictated by the data sources. In particular, 1964 is the starting date of a modern and unified system of National Accounts for the Spanish economy, and 2013 is the last year for which the human capital data of Mas et al. (2014) are available.

As we are interested in finding a long-run relationship between GDP and its possible determinants, our econometric methodology will be based on cointegration analysis; see Dolado et al. (1990) for a survey. Such a methodology is appropriate when the variables at hand have a unit root (i.e. when its first difference is stationary) to avoid the possibility of a spurious regression. Accordingly, our first step will be examining the time series properties of the series using the tests of $\mathrm{Ng}$ and Perron (2001), which try to solve the main problems present in the conventional tests for unit roots. According to the results shown in Table 1, the null hypothesis of a unit root was not rejected in all cases, whereas the null of a second unit root was always rejected, except for the variable $L F K$. However, as conventional unit root tests are biased towards accepting the null of a unit root when the series is stationary with a structural break, we have performed the modified augmented Dickey-Fuller test of Perron (1989) that allows for a breakpoint on the variable of interest. Two alternative models have been considered, namely, the innovational outlier model (IOM), which assumes that the break occurs gradually, and the additive outlier model (AOM), which assumes that the break occurs immediately. The results, shown in Table 2, allow us to reject the null hypothesis of a 
AEA

30,90

268 second unit root in $L F K$ for both the models, once we take into account a break at the year 2000, which might be related to the start of EMU and the introduction of the euro on world financial markets in 1999.

In Table 3, we present the estimation of the empirical model given by equation (5), i.e. an equation such as the following:

$$
L Y_{t}=\kappa+\alpha L K_{t}+\beta L N_{t}+\gamma L H_{t}+\theta L F K_{t}+\varepsilon_{t}
$$

\begin{tabular}{lcccc}
\hline & $M Z_{\alpha}$ & $M Z_{t}$ & $M S B$ & $M P_{T}$ \\
\hline A) $I(2)$ vs $I(1)$ & & & & \\
$\Delta L Y$ & $-8.808^{\mathrm{b}}$ & $-1.897^{\mathrm{c}}$ & $0.215^{\mathrm{b}}$ & $3.527^{\mathrm{c}}$ \\
$\Delta L K$ & $-9.064^{\mathrm{b}}$ & $-1.952^{\mathrm{c}}$ & $0.215^{\mathrm{b}}$ & $3.364^{\mathrm{c}}$ \\
$\Delta L N$ & $-9.176^{\mathrm{b}}$ & $-2.074^{\mathrm{b}}$ & $0.226^{\mathrm{b}}$ & $2.930^{\mathrm{b}}$ \\
$\Delta L H$ & $-8.347^{\mathrm{b}}$ & $-1.923^{\mathrm{c}}$ & $0.230^{\mathrm{b}}$ & $3.381^{\mathrm{c}}$ \\
$\Delta L F K$ & -2.803 & -1.089 & 0.388 & 8.450 \\
B) $I(1)$ vs $I(0)$ & & & & \\
$L Y$ & -0.128 & -0.076 & 0.594 & 23.56 \\
$L K$ & -1.669 & -0.673 & 0.403 & 11.11 \\
$L N$ & -6.307 & -1.657 & 0.263 & 4.269 \\
$L H$ & -2.001 & -0.786 & 0.393 & 10.19 \\
$L F K$ & 1.104 & 0.946 & 0.857 & 53.94
\end{tabular}

Table 1.

$\mathrm{Ng}-$ Perron tests for unit roots

Notes: ${ }^{\mathrm{b}}$ and ${ }^{\mathrm{c}}$ denote significance at the $5 \%$ and $10 \%$ levels, respectively. The critical values are taken from $\mathrm{Ng}$ and Perron (2001)

\begin{tabular}{|c|c|c|}
\hline & $\begin{array}{c}\mathrm{IOM} \\
t \tilde{\alpha}\end{array}$ & $\begin{array}{c}\mathrm{AOM} \\
t \tilde{\alpha}\end{array}$ \\
\hline $\begin{array}{l}\text { A) } I(2) \text { vs } I(1) \\
\Delta L F K\end{array}$ & $-3.995^{b}$ & $-3.984^{b}$ \\
\hline $\begin{array}{l}\text { B) } I(1) \text { vs } I(0) \\
L F K\end{array}$ & 0.490 & 0.724 \\
\hline
\end{tabular}

Table 2.

Perron tests for unit roots with breakpoints

\begin{tabular}{llc} 
& Constant & $6.465^{\mathrm{a}}(353.30)$ \\
& $L K$ & $0.236^{\mathrm{a}}(32.76)$ \\
& $L N$ & $0.107^{\mathrm{b}}(7.305)$ \\
& $L H$ & $0.243^{\mathrm{a}}(60.12)$ \\
Table 3. & $L F K$ & $0.039^{\mathrm{a}}(8.232)$ \\
Long-run & $R^{2}$ & 0.997 \\
determinants of GDP, & $C R \hat{Z}_{t}$ & $-5.580^{\mathrm{b}}$ \\
1964-2013 & $C R \hat{Z}_{\alpha}$ & $-31.23^{\mathrm{c}}$ \\
(dependent variable: & Notes: & \\
$L Y)$ & Phillips-Ouliaris cointegration tests are taken from MacKinnon (1996) & \\
\hline
\end{tabular}


where $\kappa$ denotes a constant, and $\varepsilon_{t}$ is an error term, using the fully-modified OLS (FM-OLS) method of Phillips and Hansen (1990). This method tries to eliminate the potential biases that could appear when estimating under OLS, by computing a class of Wald tests, modified by semiparametric corrections for serial correlation and endogeneity bias. The long-run covariance matrix has been estimated using the method of Newey and West (1987). Notice that the figures in parentheses are the Phillips and Hansen's fully-modified Wald test statistics on the null hypothesis that the estimated coefficients are equal to zero, asymptotically distributed as a $\chi^{2}$ with one degree of freedom. We also show the coefficient of determination $R^{2}$, and the two cointegration tests, namely, $C R \hat{Z}_{t}$ and $C R \hat{Z}{ }_{\alpha}$, proposed by Phillips and Ouliaris (1990). The estimated equation includes a dummy variable for the year 1965 to control for an atypical residual at that year.

As can be seen, all the estimated coefficients are positively signed and statistically significant at the $1 \%$ level (except for the coefficient on $L N$, which is significant at the $5 \%$ level); in particular, the proxy for the foreign capital stock appears with a small but significant coefficient. Finally, the two cointegration tests allow us to reject the null hypothesis of no cointegration at the $5 \%$ and $10 \%$ significance levels, respectively.

Now, we proceed to compute the contributions of the different explanatory variables appearing in the equation above (i.e. physical capital, labour, human capital and foreign capital) on the accumulated growth of GDP over the period of analysis. These contributions were obtained as the product of the estimated coefficient in Table 3 and the accumulated growth rate of each variable, and the results are shown in Table 4. Firstly, our estimated equation explains 2.72 points (i.e. $93.6 \%$ ) of the actual 2.91 points of accumulated growth of GDP over the period. The most important source of growth would have been human capital followed by physical capital, which explains 1.45 and 0.80 points of the actual accumulated GDP growth (i.e. $49.9 \%$ and $27.5 \%$ of total), whereas labour explains 0.08 points (i.e. $2.6 \%$ of total). Finally, we found a sizeable contribution of foreign capital to the accumulated growth of GDP over the period of 0.39 points (i.e. $13.6 \%$ of total).

We have tested for the possible presence of structural change in the previously estimated equation by means of the tests of Bai and Perron (1998, 2003a). These authors have proposed a sequential procedure method to detect endogenously multiple unknown breaks, as well as several test statistics, to identify the following possible break points:

- the UDmax and WDmax tests of the null hypothesis of no structural break versus the alternative of an unknown number of breaks given some upper bound;

- an $F$-type test of the null hypothesis of no structural break versus the alternative of a fixed (arbitrary) number of breaks; and

- a sequential $F$-type test of the null hypothesis of $l$ breaks versus the alternative of $l+1$ breaks.

\begin{tabular}{lccc}
\hline Variable & Accumulated growth & Estimated coefficient & Contribution \\
\hline Physical capital & 3.388 & 0.236 & 0.798 \\
Labour & 0.712 & 0.107 & 0.076 \\
Human capital & 5.973 & 0.243 & 1.450 \\
Foreign capital & 10.199 & 0.039 & 0.394 \\
Total & - & - & 2.719
\end{tabular}

Note: The actual accumulated growth rate of $Y$ over the whole period is 2.906

Source: Own elaboration

Role of foreign direct investment in growth

269

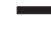


AEA

30,90

\section{0}

The results of the Bai and Perron tests appear in Table 5, where we show the UDmax and $W D$ max tests and the $F$ statistics scaled by the number of varying regressors (all of them, in our case) for the other tests. We have allowed up to three breaks with a trimming percentage of $20 \%$, so that each regime is restricted to have at least 10 observations. As the UDmax and WDmax tests are significant, at least one break is present. The scaled $F(1), F(2)$ and $F(3)$ tests are also significant at the $5 \%$ level, which means that there is at least one break. In turn, both the scaled $F(1 \mid 0)$ and $F(2 \mid 1)$ tests are significant, unlike $F(3 \mid 2)$, so the procedures detect two breaks estimated at 1974 and 1984. The first break would be associated with the first oil crisis, which brought to an end the outstanding growth rates enjoyed by the Spanish economy over the 1960s and the first 1970s. In turn, the second break would be related to the low growth years following the second oil crisis, until economic growth could return after the Spanish integration into the now EU.

Next, we have re-estimated equation (5) for the three subperiods delimited by the structural breaks found by the tests of Bai and Perron, i.e. 1964-1973, 1974-1983 and 19842013; the estimation results and their related contributions to growth are shown in Tables 6 and 7 , respectively. Notice that these results should be taken with high doses of scepticism, given the small number of observations available for every subperiod. This problem is particularly serious for the first two subperiods, including just 10 observations each; in turn, the results for the third subperiod (which includes a dummy variable for the year 2005) are in line with those found for the whole period. With all these caveats in mind, given explained

Tests

$U D \max$

555.54

WDmax

635.02

Scaled $F(1)$

555.54

Scaled $F(2)$

521.10

Scaled $F(3)$

447.67

Scaled $F(1 \mid 0)$

555.54

Scaled $F(2 \mid 1)$

37.352

Scaled $F(3 \mid 2)$

$14.612^{*}$

Number of breaks selected

2

Table 5.

Bai-Perron tests for structural change

Notes: All the test statistics are significant at the 5\% level, except the one denoted with *. The critical values are taken from Bai and Perron (2003b)

\begin{tabular}{lccc}
\hline & $1964-1973$ & $1974-1983$ & $1984-2013$ \\
\hline Constant & $-7.499^{\mathrm{b}}(3.926)$ & $12.41^{\mathrm{b}}(4.131)$ & $6.933^{\mathrm{a}}(8730.0)$ \\
$L K$ & $-0.056(0.195)$ & $-0.043(0.079)$ & $0.126^{\mathrm{a}}(99.02)$ \\
$L N$ & $1.944^{\mathrm{a}}(24.58)$ & $-0.009(0.000)$ & $0.162^{\mathrm{a}}(55.78)$ \\
$L H$ & $0.178^{\mathrm{b}}(6.066)$ & $0.282^{\mathrm{a}}(87.40)$ & $0.337^{\mathrm{a}}(491.84)$ \\
$L F K$ & $0.157^{\mathrm{a}}(96.97)$ & $-0.093^{\mathrm{b}}(4.192)$ & $0.016^{\mathrm{b}}(5.329)$ \\
$R^{2}$ & $0.997^{\mathrm{a}}$ & $0.987^{\mathrm{a}}$ & $0.999^{\mathrm{c}}$ \\
$C R \hat{Z}_{t}$ & $-8.741^{\mathrm{a}}$ & $-5.766^{\mathrm{c}}$ & $-5.050^{\mathrm{c}}$ \\
$C R \hat{Z}_{\alpha}$ & -8.884 & -9.769 & $-26.45^{\mathrm{c}}$
\end{tabular}


accumulated growth rates of 5.86, 1.33 and 2.30 for each subperiod, and focussing on our variable of interest, i.e. the foreign capital stock, its contribution to growth would have been $2.81,-0.14$ and 0.16 points (i.e. $48.6 \%,-11.4 \%$ and $7.2 \%$ of total), respectively.

In other words, according to the information shown in Table 7, the role of foreign capital was much greater between 1964 and 1973 (a period in which its accumulated rate of growth reached 18\%), fell to negative figures between 1974 and 1983 (a crisis period in which its accumulated rate of growth was hardly 1.5\%) [2] and became positive again between 1984 and 2013 (when the growth of the foreign capital stock resumed at an accumulated rate of $10.4 \%$ ), although at a much slower pace than in the first subperiod. These results, on the other hand, can be confirmed from a different point of view by computing the recursive estimate of the coefficient on $L F K$ from the estimation of equation (5). Specifically, the equation is estimated repeatedly, starting from a number of observations equal to that of the coefficients to be estimated and adding successively one more observation to the data set until all the sample points are used. The results, together with \pm 2 standard errors, appear in Figure 1 and show that, after reaching a maximum in 1972, the value of the estimated coefficient falls continuously until the end of the sample period. In other words, the effect of foreign capital on GDP would decrease steadily along time, confirming the above results.

Finally, for the sake of completeness, and given the possibility of a bi-directional causal relationship between FDI and economic growth, we have performed Grangercausality tests on the variables GDP and foreign capital stock. The tests have been performed in a multivariate setting, i.e. including the other variables used in our empirical analysis (physical capital, labour and human capital), to avoid possible spurious results because of the omission of those variables. Notice that, if the variables under analysis have a unit root and are cointegrated, as in this case, Granger-causality tests should be performed on the variables in first differences,

\begin{tabular}{lccr}
\hline Variable & Accumulated growth & Estimated coefficient & Contribution \\
\hline A) 1964-1973 & & & \\
Physical capital & 4.436 & -0.056 & -0.247 \\
Labour & 0.889 & 1.944 & 1.728 \\
Human capital & 8.803 & 0.178 & 1.568 \\
Foreign capital & 17.901 & 0.157 & 2.812 \\
Total & - & - & 5.862 \\
B) 1974-1983 & & & \\
Physical capital & 3.428 & -0.043 & -0.148 \\
Labour & -1.232 & -0.009 & 0.011 \\
Human capital & 5.697 & 0.282 & 1.609 \\
Foreign capital & 1.509 & -0.093 & -0.140 \\
Total & - & - & 1.331 \\
C) 1984-2013 & & & \\
Physical capital & 2.597 & 0.126 & 0.328 \\
Labour & 1.382 & 0.162 & 0.224 \\
Human capital & 4.715 & 0.337 & 1.590 \\
Forign capital & 10.358 & 0.016 & 0.163 \\
Total & - & - & 2.304
\end{tabular}

Note: The actual accumulated growth rates of $Y$ over each subperiod are 5.788, 1.231 and 2.275, respectively

Source: Own elaboration
Role of foreign direct investment in growth

271
Table 7. Contributions to economic growth over subperiods (percentage points) 
AEA

30,90

\section{2}

Figure 1.

Recursive estimate of the coefficient on LFK

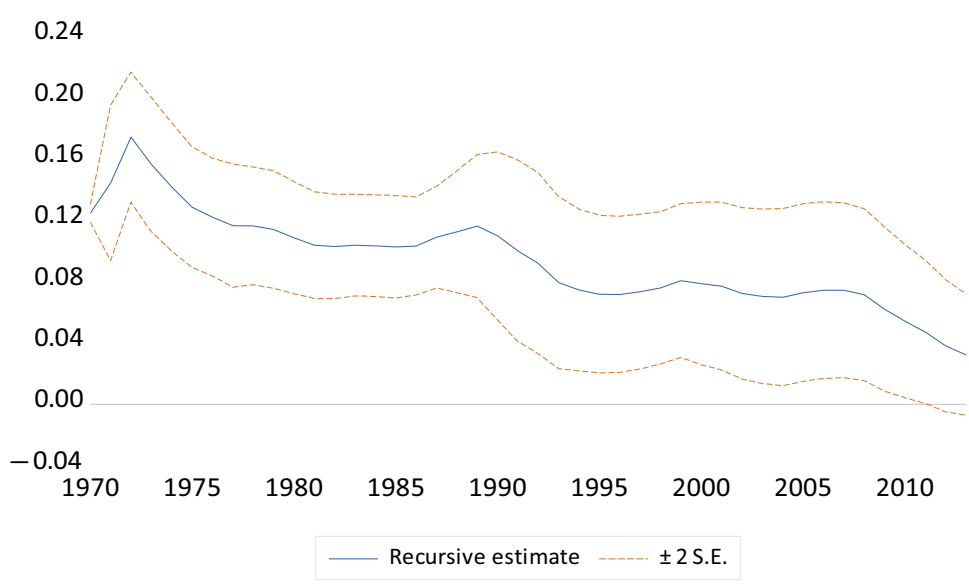

including an error-correction term (i.e. the residuals of the cointegrating regression). According to Granger (1988), if there is cointegration between a pair of variables, there must be causality between them in at least one direction to provide these variables with enough dynamics to reach the equilibrium. Hence, we have estimated the following equations of the form:

$$
\begin{aligned}
\Delta L Y_{t}= & \kappa+\sum_{i=1}^{p} \alpha_{i} \Delta L K_{t-i}+\sum_{j=1}^{q} \beta_{j} \Delta L N_{t-j}+\sum_{k=1}^{r} \gamma_{k} \Delta L H_{t-k}+\delta E C M_{t-1}+u_{t} \\
\Delta L Y_{t}= & \kappa+\sum_{i=1}^{p} \alpha_{i} \Delta L K_{t-i}+\sum_{j=1}^{r} \beta_{j} \Delta L N_{t-j}+\sum_{k=1}^{r} \gamma_{k} \Delta L H_{t-k}+\sum_{l=1}^{s} \theta_{l} \Delta L F K_{t-l} \\
& +\delta E C M_{t-1}+v_{t}
\end{aligned}
$$

With an analogous representation holding for $\triangle L F K_{t}$ as dependent variable, where $E C M$ denotes the error-correction mechanism, i.e. the residuals of the estimation of equation (5). Accordingly, to test for Granger-causality, the null hypotheses would be $\delta=0$ for the absence of long-run causality, and $\theta_{l}=0$ for the absence of short-run causality; and the standard $F$ test can be used to test for Granger-causality in the short and in the long run.

The results of the Granger-causality tests are shown in Table 8. The number of lags was selected using the Schwarz criterion. Up to two lags of the variables were tried, and the best

$F$-statistic

Probability

A) Null hypothesis: LFK does not Granger-cause LY

Test on ECM

6.692

0.014

Test on lags of $\triangle L F K$

0.812

0.373

B) Null hypothesis: LY does not Granger-cause LFK

Test on ECM

0.953

0.335

Test on lags of $\Delta L Y$ 
results were obtained with one lag for all variables, except for $\Delta L K$, when testing for Granger causality of $\triangle L F K$ on $\triangle L Y$, where two lags were chosen. As can be seen, it is possible to reject the null hypothesis of no Granger causality from foreign capital to GDP in the long run but not in the short run, whereas the null hypothesis of no Granger causality from GDP to foreign capital is not rejected both in the long run and the short run. Again, these results would support the previous finding of a long-run relationship between foreign capital and GDP, which would run from the former to the latter.

Role of foreign direct investment in growth

273

\section{Conclusions}

The objective of this paper has been to analyse the long-run effects of FDI in Spain by estimating a production function, including the foreign capital stock, over the period 19642013. The estimation of the production function for the whole period gave a small, positive but significant coefficient on the foreign capital stock, together with positive and statistically significant coefficients on the rest of variables (i.e. physical capital, labour and human capital); in addition, the estimated relationship was a long-run one, as evidence of cointegration among the variables was found. When computing the contributions of the different explanatory variables on the accumulated growth of GDP over the period of analysis, we obtained that the foreign capital stock would have accounted for $13.6 \%$ of the actual accumulated GDP growth, at the same time that human capital, physical capital and labour explained $49.9 \%, 27.5 \%$ and $2.6 \%$, respectively, of total accumulated GDP growth.

Next, we tested for the possible presence of structural change in the previously estimated equation by means of the tests of Bai and Perron, finding two breaks estimated at 1974 and 1984. When re-estimating the production function for the three subperiods delimited by these structural breaks, i.e. 1964-1973, 1974-1983 and 1984-2013, we found that the contribution of the foreign capital stock on accumulated growth of GDP was much greater between 1964 and 1973, fell to negative figures between 1974 and 1983, and became again positive between 1984 and 2013 but at a much slower pace than in the first subperiod. These results should be taken with care, however, given the small number of observations available for every subperiod, especially for the first two subperiods, although they were confirmed when computing the recursive estimate of the coefficient on the foreign capital stock from the estimation of the production function over the whole sample period.

Finally, given the possibility of a bi-directional causal relationship between FDI and economic growth, we performed Granger-causality tests on the variables GDP and foreign capital stock in a multivariate setting, including an error-correction term, given the finding of cointegration among the variables under study. According to the results, Granger causality from foreign capital to GDP appeared in the long run but not in the short run, whereas Granger causality from GDP to foreign capital did not appear both in the long run and the short run.

In general, the results of this paper suggest that foreign capital can play a positive role on the economic growth of an economy, provided that FDI inflows are stable and permanent enough. Such a favourable effect on growth might be more important in the first stages of a growth process. And, in any case, to reach a higher GDP growth, the host countries should possess a minimum social capability in the form of an educated labour force and adequate organizational structures; in other words, the necessary absorptive capacity to incorporate in a satisfactory way the advanced technologies usually associated with FDI. In particular, an implication of the results of the paper would be that the more advanced technologies brought about by FDI should have been more necessary and relevant over the first years of the period analysed, but not so much later on, once the Spanish economy became more developed and less dependent on those foreign cutting-edge technologies. 
1. Notice that, given the policy of autarky followed by the Spanish authorities over the period 19391959, FDI inflows would have been negligible before 1960.

2. Notice that the negative coefficient on $L F K$ shown in Table 6 might be related to the reduced number of observations available for this subperiod.

\section{4}

\section{References}

Adams, S. (2009), "Foreign direct investment, domestic investment, and economic growth in SubSaharan Africa", Journal of Policy Modeling, Vol. 31 No. 6, pp. 939-949.

Aitken, B.J. and Harrison, A.E. (1999), "Do domestic firms benefit from direct foreign investment? Evidence from Venezuela”, American Economic Review, Vol. 89 No. 3, pp. 605-618.

Alfaro, L., Chanda, A., Kalemli-Ozcan, S. and Sayek, S. (2004), "FDI and economic growth: the role of local financial markets", Journal of International Economics, Vol. 64 No. 1, pp. 89-112.

Bai, J. and Perron, P. (1998), "Estimating and testing linear models with multiple structural changes", Econometrica, Vol. 66 No. 1, pp. 47-78.

Bai, J. and Perron, P. (2003a), "Computation and analysis of multiple structural change models”, Journal of Applied Econometrics, Vol. 18 No. 1, pp. 1-22.

Bai, J. and Perron, P. (2003b), "Critical values for multiple structural change tests", The Econometrics Journal, Vol. 6 No. 1, pp. 72-78.

Bajo-Rubio, O. and López-Pueyo, C. (2002), "Foreign direct investment in a process of economic integration: the case of Spanish manufacturing, 1986-1992", Journal of Economic Integration, Vol. 17 No. 1, pp. 85-103.

Bajo-Rubio, O. and Sosvilla-Rivero, S. (1994), "An econometric analysis of foreign direct investment in Spain, 1964-89”, Southern Economic Journal, Vol. 61 No. 1, pp. 104-120.

Bajo-Rubio, O. and Torres, A. (1992), "El comercio exterior y la inversión extranjera directa tras la integración de españa en la CE (1986-90)”, in Viñals, J. (Ed.), La economía española ante el Mercado Único europeo. Las claves del proceso de integración, Alianza, Madrid, pp. 167-228.

Bajo-Rubio, O., Díaz-Mora, C. and Díaz-Roldán, C. (2010), "Foreign direct investment and regional growth: an analysis of the Spanish case”, Regional Studies, Vol. 44 No. 3, pp. 373-382.

Balasubramanyam, V.N., Salisu, M. and Sapsford, D. (1996), "Foreign direct investment and growth in EP and IS countries", The Economic Journal, Vol. 106 No. 434, pp. 92-105.

Barrios, S., Görg, H. and Strobl, E. (2005), "Foreign direct investment, competition and industrial development in the host country", European Economic Review, Vol. 49 No. 7, pp. 1761-1784.

Bermejo-Carbonell, J. and Werner, R.A. (2018), "Does foreign direct investment generate economic growth? A new empirical approach applied to Spain”, Economic Geography, Vol. 94 No. 4, pp. $425-456$.

Blomström, M. and Kokko, A. (1998), "Multinational corporations and spillovers", Journal of Economic Surveys, Vol. 12 No. 3, pp. 247-277.

Blomström, M., Lipsey, R.E. and Zejan, M. (1994), "What explains the growth of developing countries?”, in Baumol, W.J., Nelson, R.R. and Wolff, E.N. (Eds), Convergence of Productivity: Cross-National Studies and Historical Evidence, Oxford University Press, Oxford, pp. 243-259.

Borensztein, E., De Gregorio, J. and Lee, J.-W. (1998), "How does foreign direct investment affect economic growth?”, Journal of International Economics, Vol. 45 No. 1, pp. 115-135.

Brems, H. (1970), "A growth model of international direct investment”, American Economic Review, Vol. 60, pp. 320-331. 
Campos, N.F. and Kinoshita, Y. (2002), "Foreign direct investment as technology transferred: some panel evidence from the transition economies", The Manchester School, Vol. 70 No. 3, pp. 398-419.

de Mello, L.R. (1999), "Foreign direct investment-led growth: evidence from time series and panel data", Oxford Economic Papers, Vol. 51 No. 1, pp. 133-151.

Role of foreign direct investment in growth

Durham, J.B. (2004), "Absorptive capacity and the effects of foreign direct investment and equity foreign portfolio investment on economic growth", European Economic Review, Vol. 48 No. 2, pp. 285-306.

Fernández-Otheo, C.M. (2003), Inversión directa extranjera de España en la década final del siglo XX: Nuevas perspectivas, Fundación José Ortega y Gasset, Madrid.

Fundación BBVA and Ivie (2019), "El stock y los servicios del capital en España y su distribución territorial y sectorial (1964-2016)", available at www.fbbva.es/TLFU/microsites/stock09/ fbbva_stock08_index.html

Görg, H. and Greenaway, D. (2004), "Much ado about nothing? Do domestic firms really benefit from foreign direct investment?", World Bank Research Observer, Vol. 19, pp. 171-197.

Granger, C.W.J. (1988), "Some recent development in a concept of causality", Journal of Econometrics, Vol. 39 Nos 1/2, pp. 199-211.

Grossman, G.M. and Helpman, E. (1991), Innovation and Growth in the Global Economy, The MIT Press, Cambridge, MA.

Grossman, G.M. and Helpman, E. (1994), "Endogenous innovation in the theory of growth", Journal of Economic Perspectives, Vol. 8 No. 1, pp. 23-44.

Gutiérrez-Portilla, P., Maza, A. and Villaverde, J. (2019), "A spatial approach to the FDI-growth nexus in Spain: dealing with the headquarters effect", International Business Review, Vol. 28 No. 6, art. 101597.

Iamsiraroj, S. (2016), "The foreign direct investment-economic growth nexus", International Review of Economics and Finance, Vol. 42, pp. 116-133.

Laureti, L. and Postiglione, P. (2005), "The effects of capital inflows on the economic growth in the Med Area", Journal of Policy Modeling, Vol. 27 No. 7, pp. 839-851.

Lipsey, R.E. (2001), "Interpreting developed countries' foreign direct investment", in Deutsche Bundesbank: Investing Today for the World of Tomorrow, Springer-Verlag, Berlin, pp. 285-325.

MacKinnon, J.G. (1996), "Numerical distribution functions for unit root and cointegration tests", Journal of Applied Econometrics, Vol. 11 No. 6, pp. 601-618.

Mankiw, N.G., Romer, D. and Weil, D.N. (1992), “A contribution to the empirics of economic growth", The Quarterly Journal of Economics, Vol. 107 No. 2, pp. 407-437.

Mas, M. Pérez, F. Serrano, L. Soler, A. and Uriel, E. (2014), Capital humano en España y su distribución provincial, Fundación Bancaja and Ivie, Valencia, available at www.ivie.es/es/banco/caphum/ series.php

Myro, R. (Ed.) (2014), España en la inversión directa internacional, Instituto de Estudios Económicos, Madrid.

Newey, W.K. and West, K.D. (1987), "A simple, positive semi-definite, heteroskedasticity and autocorrelation consistent covariance matrix", Econometrica, Vol. 55 No. 3, pp. 703-708.

$\mathrm{Ng}$, S. and Perron, P. (2001), "Lag length selection and the construction of unit root tests with good size and power", Econometrica, Vol. 69 No. 6, pp. 1529-1554.

Omri, A. and Kahouli, B. (2014), "The nexus among foreign investment, domestic capital and economic growth: empirical evidence from the MENA region”, Research in Economics, Vol. 68 No. 3, pp. 257-263. 
Perron, P. (1989), "The great crash, the oil price shock, and the unit root hypothesis", Econometrica, Vol. 57 No. 6, pp. 1361-1401.

Phillips, P.C.B. and Hansen, B.E. (1990), "Statistical inference in instrumental variables regression with I(1) processes”, The Review of Economic Studies, Vol. 57 No. 1, pp. 99-125.

Phillips, P.C.B. and Ouliaris, S. (1990), "Asymptotic properties of residual based tests for cointegration", Econometrica, Vol. 58 No. 1, pp. 165-193.

Rivera-Batiz, L.A. and Romer, P.M. (1991), "Economic integration and endogenous growth", The Quarterly Journal of Economics, Vol. 106 No. 2, pp. 531-555.

Rodríguez, X.A. and Pallas, J. (2008), "Determinants of foreign direct investment in Spain", Applied Economics, Vol. 40 No. 19, pp. 2443-2450.

Romer, P.M. (1990), "Endogenous technological change”, Journal of Political Economy, Vol. 98 No. 5, Part 2, pp. S71-S102.

Sosvilla-Rivero, S. and Herce, J.A. (1998), "Efectos macroeconómicos del Mercado Único europeo", Economia Industrial, Vol. 322, pp. 11-21.

Tang, S., Selvanathan, E.A. and Selvanathan, S. (2008), "Foreign direct investment, domestic investment and economic growth in China: a time series analysis", World Economy, Vol. 31 No. 10, pp. 1292-1309.

Villaverde, J. and Maza, A. (2012), "Foreign direct investment in Spain: regional distribution and determinants", International Business Review, Vol. 21 No. 4, pp. 722-733.

Wang, J.-Y. (1990), "Growth, technology transfer, and the long-run theory of international capital movements", Journal of International Economics, Vol. 29 Nos 3/4, pp. 255-271.

Wang, J.-Y. and Blomström, M. (1992), "Foreign investment and technology transfer. A simple model", European Economic Review, Vol. 36 No. 1, pp. 137-155.

\section{Corresponding author}

Oscar Bajo-Rubio can be contacted at: oscar.bajo@uclm.es

For instructions on how to order reprints of this article, please visit our website: 